\title{
Antifungal activity and resistance induction against Sclerotium cepivorum by plant growth-promoting fungi in onion plants
}

\author{
Mohsen Mohamed Elsharkawy ${ }^{1 *}$ (D) and Nagwa Mohamed Mohamed El-Khateeb ${ }^{2}$
}

\begin{abstract}
The influence of the inoculation with plant growth-promoting fungi (PGPF) isolates on growth enhancement of onion plants and progress of white rot disease in onions, caused by Sclerotium cepivorum, was evaluated. The tested PGPF isolates were Phoma sp. GS8-1, Phoma sp. GS 8-3, Trichoderma asperellum SKT-1, Fusarium equiseti GF18-3 and Penicillium simplicissmum GP17-2. Abnormal shape and lysis in the mycelia of the pathogen were reported in dual cultures of PGPF and S. cepivorum using scanning electron microscopy. The germination of sclerotia was reduced after soaking in culture filtrates of PGPF. The highest reduction was recorded in $P$. simplicissmum GP17-2 treatment (70.85\%). The results demonstrated that the treatments with PGPF isolates significantly enhanced the plant height, root length, bulb perimeter and plant dry weight. Additionally, PGPF clearly reduced disease severity of white rot disease of onions. Among PGPF isolates, T. asperellum SKT-1 and P. simplicissmum GP17-2 showed the best effects in reducing the incidence and severity of white rot and enhancing onion growth. On the other hand, the levels of peroxidase and polyphenol oxidase were improved in the treated onion plants than in the untreated plants at 7 days after induction treatments. Similarly, early and strong expressions of defence genes, PR1 and PR2, were reported in plants treated with PGPF. Overall, this research suggested that PGPF treatments generated favourable effects on the suppression of white rot disease of onions.
\end{abstract}

Keywords: Antifungal activity, Resistance, Induced systemic resistance, Plant growth-promoting fungi (PGPF), Sclerotium cepivorum, Onion, White rot

\section{Background}

Onion plants are subjected to infection with many diseases that affect the yield quantity and quality. Sclerotium cepivorum Berk. is a dangerous and widespread pathogen affecting onion production all over the world. Onion white rot is a severe disease not only causing losses in the yield of bulbs, but also in soil infestation with the pathogen, which makes it unsuitable for onion production for more than 15 years. Sclerotia of the pathogen stay in inactive conditions with fungistasis in the soil (Hyakumachi et al. 2014). Aqueous extracts and exudates of onions enhance the germination of sclerotia (Reddy 1992).

Approaches for the control of white rot disease still depend on the chemical fungicides. However, the

\footnotetext{
* Correspondence: mohsen.abdelrahman@agr.kfs.edu.eg

'Department of Agricultural Botany (Plant Pathology), Faculty of Agriculture, Kafrelsheikh University, Kafr Elsheikh 33516, Egypt

Full list of author information is available at the end of the article
}

intensive use of these compounds for controlling plant diseases causes serious problems not only to the environment but also to human health. Additionally, some pesticides have shown phytotoxicity and also inconsistent control of S. cepivorum (Ryan and Kavanagh 1976). These reasons emphasize the need for new methods to control plant diseases. One of the main alternatives to fungicides is biological control. Many beneficial microorganisms are being used as biocontrol agents (BCAs). Plant growth-promoting fungi (PGPF) are non-pathogenic soil-living fungi (Hyakumachi 1994) reported to improve plant growth and health after treatments in several plants (Elsharkawy et al. 2012; Hassan et al. 2014). PGPF are usually useful for controlling soil-borne fungi (Saldajeno and Hyakumachi 2011). Payghami (2001) successfully used Trichoderma harzianum and Trichoderma viride to prevent the infection with S. cepivorum. He also found 
that both isolates (obtained from the mycoflora of onion rhizosphere) significantly increased the growth of onion plants in pots. Additionally, Clarkson et al. (2002) studied the ability of certain bioagents against the white rot of onions. Two of the potential bioagents were both recognized as $T$. viride (L4 and S17 A). They added that L4 and S17A were used for onion bulbs treatment which resulted in significantly reduced the white rot symptoms under field conditions.

Biocontrol agents (BCAs) restrict plant pathogens by a series of mechanisms such as antibiosis, fungistasis, induced systemic resistance, hyperparasitism and/or modification of the rhizosphere (Elsharkawy et al. 2012). Defence of plants against pathogens is regulated through a complex of peroxidase and polyphenol oxidase activities (Hassan et al. 2014). Some reports stated that peroxidase and polyphenol oxidase are important enzymes associated with the stimulated systemic resistance (Rasmussen et al. 1995). Activities of peroxidase and polyphenol oxidase were increased in cucumber plants treated with PGPF against the infection of anthracnose disease (Hassan et al. 2014). On the other hand, upregulation of pathogenesis-related (PR) genes is a common indicator of defence response and highly related to the improved resistance against different pathogens (Elsharkawy et al. 2012).

The aim of this study was to investigate the effect of the PGPF isolates on crop parameters and induced resistance against the white rot of onions.

\section{Materials and methods}

\section{Isolation and identification of the causal pathogen}

Infected samples exhibiting standard symptoms of the white rot disease were collected from different locations in Egypt such as Kafr El-Sheikh (KS), Qutour (QT), Mahalet Rough (MR) and Negrig (NG). Isolation of sclerotia of the causal pathogen was carried out as described by Utkhede and Rahe (1979) to get pure cultures on potato dextrose agar (PDA). The isolated fungus was identified as Sclerotium cepivorum in Kafrelsheikh University, Egypt, based on Gilman (1957). Pathogenicity test was carried out in plastic pots using four isolates of S. cepivorum on onion seedlings (Giza-20) under greenhouse conditions following the method of El-Sheshtawi et al. (2009). Inocula of S. cepivorum isolates grown on barley grains were prepared following the method reported by Abd El-Moity (1976). Wellmixed inoculum from each isolate (at a concentration of $2 \% \mathrm{w} / \mathrm{w}$ ) with sterilized clay soil (with $5 \%$ formalin) was placed in sterilized pots ( $25 \mathrm{~cm}$ in diameter). All pots were irrigated every other day starting from 14 days before planting to guarantee the development of the pathogen. PGPF isolates, Phoma sp. GS8-1, Phoma sp. GS 8-3, T. asperellum SKT-1, F. equiseti GF18-3 and P. simplicissmum GP17-2, were grown on PDA (Hyakumachi 1994).
Evaluation of the antagonistic effect of PGPF isolates against $S$. cepivorum

The antagonism of PGPF isolates toward S. cepivorum (NG) was tested according to the dual culture protocols described by Bell et al. (1982). Mycelial discs ( $5 \mathrm{~mm}$ ) obtained from the active PGPF cultures (grown on PDA medium) were inoculated on the side of a medium, and on the opposite side, a disc of S. cepivorum was inoculated then the plates were incubated at $17^{\circ} \mathrm{C}$ for 2 weeks. The growth area, average of inhibition zone and number of sclerotia of $S$. cepivorum (NG) were measured. Five Petri dishes were used for each PGPF isolate.

\section{Microscopic examination}

Scanning electron microscopy (SEM) was utilized to evaluate the effects of $P$. simplicissmum GP17-2 and $T$. asperellum SKT-1 (the most effective biological control agents compared with other bioagents) on the growth of $S$. cepivorum. The samples were prepared by fixation and dehydration methods. The samples were immersed in $3 \%$ glutaraldehyde and phosphate buffer $(0.1 \mathrm{M})$ for $3.5 \mathrm{~h}$ at room temperature. Samples were washed three times by sterilized distilled water (SDW). Samples were post-fixed in osmium tetroxide at room temperature for $2 \mathrm{~h}$ and washed again. The fixed specimens were dehydrated in stepwise ethanol concentrations and dried at critical point (CPD). The specimens were covered by a metal coating and sputter coating. The samples were examined with a field emission electron microscope (TESLA BS-300) in the Faculty of Agriculture, Mansoura University, Egypt.

\section{Evaluation of the antagonistic effect of cultural filtrates of PGPF}

The effects of cultural filtrates (CFs) of PGPF isolates on sclerotial germination were evaluated. CFs of PGPF isolates were prepared by inoculating potato dextrose broth medium (250 ml PDB) with 20 mycelial discs $(5 \mathrm{~mm})$ from the edge of the PGPF cultures and incubated for 11 days at $23^{\circ} \mathrm{C}$ (Elsharkawy et al. 2012). CFs were filtered through a sterile Whatman ${ }^{\text {tw }}$ filter paper grade 2 then a sterile Millipore filter $(0.22 \mathrm{~mm})$ was used. CFs were transferred to Petri dishes, and then the plates were inoculated in the centre with a disc from S. cepivorum and incubated for 2 weeks at $17^{\circ} \mathrm{C}$. The diameter of $S$. cepivorum colony was measured. The percentage of germinated sclerotia was recorded. Non-inoculated PDB was served as control. Six Petri dishes were used for each PGPF isolate.

\section{Barley grain inoculum of PGPF}

Autoclaved barley grains (100 g in $100 \mathrm{ml}$ distilled water) were inoculated by 12-18 mycelial discs from active cultures of PGPF isolates grown on PDA and incubated at 
Table 1 Sequence of primers used in qRT-PCR analysis

\begin{tabular}{lll}
\hline Prime & Direction & Sequence 5'-3' \\
\hline PR1 & Forward & TTCTTCCCTCGAAAGCTCAA \\
& Reverse & CGCTACCCCAGGCTAAGTIT \\
PR2 & Forward & TCCGGGGTATGTTATGGAAGA \\
& Reverse & GGCCATCCACTCTCAGACACA \\
EF1a & Forward & ATTGGAAACGGATATGCTCCA \\
& Reverse & TCCTTACCTGAACGCCTGTCA \\
\hline
\end{tabular}

$22{ }^{\circ} \mathrm{C}$ for $12-14$ days with shaking at 4 days intervals. The inoculum was dried then ground to $1 \mathrm{~mm}$ and kept in a refrigerator until use.

\section{Pot experiments}

Two pot experiments were performed separately and repeated three times under greenhouse conditions.

\section{Measuring growth enhancement}

Pots $(25 \mathrm{~cm}$ in diameter) were filled with clay soil blended with each of the PGPF isolates (at inocula rates $2 \% \mathrm{w} / \mathrm{w})$, giving a total of seven treatments for the experiment: (a) Phoma sp. GS8-1, (b) Phoma sp. GS 8-3, (c) T. asperellum SKT-1, (d) F. equiseti GF18-3, (e) P. simplicissmum GP17-2, (f) the fungicide Folicur ${ }^{\circ} 250$ EC $(25 \mathrm{ml} / \mathrm{l})$ and $(\mathrm{g})$ uninoculated control (control). Three onion transplants (60 days old) from the cultivar Giza-20 were transplanted per pot. After 100 days of growth, the plants were uprooted and the shoots were separated from the roots and washed with running tap water. Plant height, root length, bulb perimeter and the shoot dry weight $\left(36 \mathrm{~h}\right.$ at $\left.80^{\circ} \mathrm{C}\right)$ were measured.

\section{Suppressive effects of PGPF isolates}

The barley grain inoculum (BGI) of each PGPF isolate $(2 \% \mathrm{w} / \mathrm{w})$ was hand-mixed thoroughly with the potting medium. The fungicide Folicur ${ }^{\oplus} 250$ EC (tebuconazole) was used as a positive control $(25 \mathrm{ml} / \mathrm{l})$. Plastic pots were filled with the inoculated soil pre-infested with the sclerotia of S. cepivorum (NG) (100 sclerotia/kg soil) as reported by Metcalf et al. (2004). Three transplants were then grown in each plastic pot of the aforementioned treatments. The plants were kept for symptom development. Three pots were used per replicate. To evaluate the disease severity, plants were uprooted after 100 days from transplanting and graded for disease severity according to the 0-100 arbitrary disease severity scale based on the described scale by Abd El-Moity (1976) and modified as follows: $0=$ no symptoms, $25=$ slight severe (small roots and yellow leaves), $50=$ moderatesevere (rotting of the roots and dieback of the leaves), 75 $=$ severe (yellowing of the whole plant and soft rot of the roots) and $100=$ highly severe (dead plants, completely rotten roots).

Disease incidence $=$ No. of infected plants $/$ No. of total plants $\times 100$ (Brix and Zinkernagel 1992).

\section{Field experiment}

A field experiment was carried out at Negrig, Gharbiah, Egypt, in a plot of clay soil naturally infected with $S$. cepivorum (Negrig isolate). The onion seedlings (Giza 20) were grown in sterilized pots filled with clay soil and treated with BGI of each PGPF isolate for 60 days. BGI of each isolate was added at a rate of $400 \mathrm{~g} / \mathrm{m}$ length of the row. Each row was $55 \mathrm{~cm}$ wide and $5 \mathrm{~m}$ long. Each treatment was repeated three times. Eighty seedlings were transplanted in each row. The fungicide Folicur ${ }^{\circ}$ $250 \mathrm{EC}$, as a dipping treatment, was used for comparison with PGPF treatments. Disease incidence was reported 140 days post-transplanting.

\section{Antioxidant enzymes}

Leaf materials $(0.5 \mathrm{~g})$ were collected from different treatments of the pot experiment. The activities of peroxidase and polyphenol oxidase enzymes were determined in onion plants, 7 days after transplanting (Anand et al. 2007). Peroxidase (POX) activity was determined according to the typical procedure described by Thimmaiah (1999). Peroxidase activity was measured spectrophotometrically (Beckman Spectrophotometer $\mathrm{Du}^{\circledR} 7400$ ) every $30 \mathrm{~s}$ up to 3 min. Polyphenol oxidase (PPO) activity was measured according to a typical method proposed by

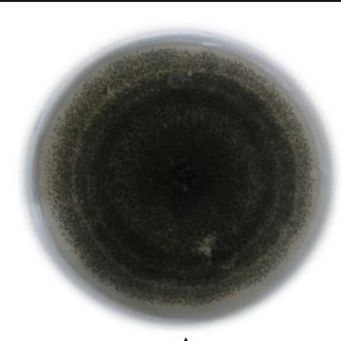

A

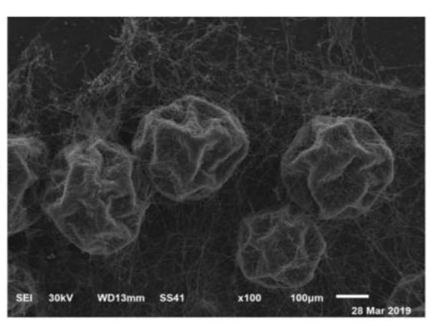

B

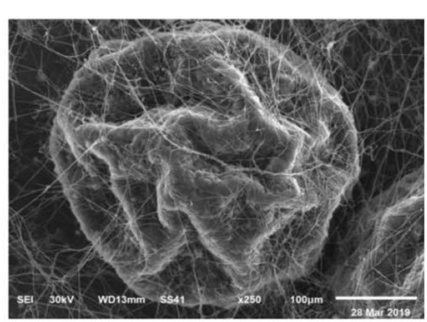

C

Fig. 1 Morphology of Sclerotium cepivorum (NG isolate) on PDA medium (a). Scanning electron microscopy (SEM) of Sclerotium cepivorum (NG isolate) sclerotia $(\mathbf{b}, \mathbf{c})$ 
Table 2 Interaction between PGPF isolates and Sclerotium cepivorum in dual cultures at 14 days after inoculation

\begin{tabular}{llll}
\hline Treatments & Average growth area $\left(\mathrm{cm}^{2}\right)$ & Average inhibition zone $\left(\mathrm{cm}^{2}\right)$ & Average no. of sclerotia $\left(\mathrm{cm}^{2}\right)$ \\
\hline Control & $68.33 \mathrm{a}$ & $0.00 \mathrm{e}$ & $82.38 \mathrm{a}$ \\
GS8-1 & $41.99 \mathrm{c}$ & $2.47 \mathrm{~b}$ & $43.98 \mathrm{c}$ \\
GS8-3 & $42.38 \mathrm{c}$ & $2.13 \mathrm{c}$ & $44.79 \mathrm{c}$ \\
SKT-1 & $27.87 \mathrm{e}$ & $0.00 \mathrm{e}$ & $41.13 \mathrm{~d}$ \\
GF18-3 & $47.31 \mathrm{~b}$ & $1.77 \mathrm{~d}$ & $49.79 \mathrm{~b}$ \\
GP17-2 & $32.92 \mathrm{~d}$ & $3.98 \mathrm{a}$ & $39.24 \mathrm{e}$
\end{tabular}

Different letters indicate statistically significant differences between treatments by Fisher's LSD test

Sadasivam and Manickam (1991). The activity was calculated as absorbance $\min ^{-1} \mathrm{~g}^{-1}$ fresh weight.

\section{Total RNA extraction and real-time PCR relative comparative analysis}

Collections of leaf samples from treated and control plants were carried out 1 week after transplanting (Elsharkawy et al. 2012). RNeasy Mini Kit was used to extract total RNA from treated and non-treated plants following the manufacturer's protocol (QIAGEN, Germany). The first- strand cDNA was synthesized as described by El-Morsi et al. (2015), and RT-PCR amplification was carried out. The housekeeping gene elongation factor $1-\alpha(E F 1-\alpha)$ and PR genes (PR1 and PR2) (Table 1) were utilized for this investigation. QRT-PCR was conducted using a SYBR Green PCR Master Mix (Fermentas, USA). Accurate quantification of relative expression ratio was calculated following typical methods described by Livak and Schmittgen (2001). Automated threshold analysis on ABI system was used to calculate the $\mathrm{C}_{\mathrm{T}}$ (threshold of the cycle) value of each detected gene.

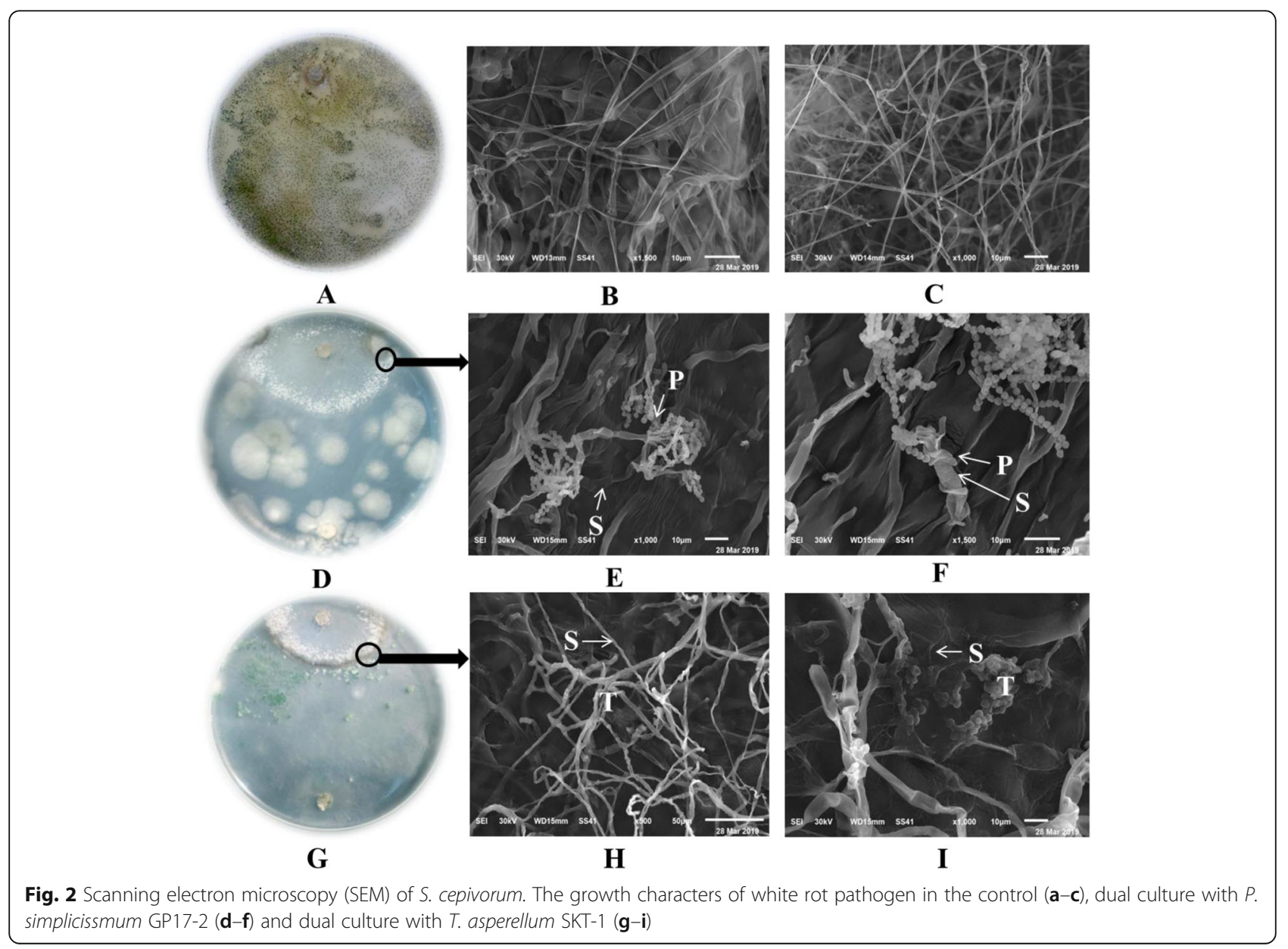


Table 3 Effect of soaking sclerotia of Sclerotium cepivorum in cultural filtrates of PGPF isolates

\begin{tabular}{lll}
\hline Treatments & Germination of sclerotia & Reduction (\%) \\
\hline Control & $97.31 \mathrm{a}$ & - \\
GS8-1 & $46.19 \mathrm{~d}$ & 52.53 \\
GS8-3 & $49.97 \mathrm{c}$ & 48.64 \\
SKT-1 & $32.72 \mathrm{e}$ & 66.38 \\
GF18-3 & $54.48 \mathrm{~b}$ & 44.01 \\
GP17-2 & $28.37 f$ & 70.85
\end{tabular}

Different letters indicate statistically significant differences between treatments by Fisher's LSD test

\section{Statistical analysis}

Analysis of variance (ANOVA) was carried out for the data by E KUSERU- T OUKEI 2010 (SSRI Co., Ltd., Japan). Fisher's least significant difference (LSD) test was used to separate treatment means. All comparisons were determined at $P \leq 0.05$.

\section{Results and discussion}

Isolates of S. cepivorum

Isolates of the pathogen were collected from severely infested soil locations in Kafr El-Sheikh, Qutour, Mahalet Rough and Negrig, identified as four isolates of $S$. cepivorum. Based on the pathogenicity test, the isolates showed different degrees of severity on onion transplants cv. Giza-20. The Negrig isolate proved to be the most aggressive (Fig. 1), while the Kafr El-Sheikh isolate exhibited the lowest severity. Due to its severity on onion plants, the NG isolate was chosen as the main isolate in this study.

Antagonistic activity of PGPF isolates against S. cepivorum The ability of PGPF isolates to inhibit the growth and germination of the sclerotia of S. cepivorum was evaluated. The interaction of PGPF isolates and S. cepivorum is presented in Table 2. T. asperellum SKT-1 hindered the development of the pathogen by growing over the colony of S. cepivorum. Phoma sp. GS 8-1 and GS 8-3 isolates exhibited inhibition zones of 2.47 and $2.13 \mathrm{~cm}^{2}$, respectively. Growth inhibition and the average number of formed sclerotia by the pathogen caused by $F$. equiseti GF18-3 and P. simplicissmum GP17-2 were 30.76 and 49.79\%, and 51.82 and $39.24 \%$, respectively. P. simplicissmum GP17-2 was the most effective one, followed by $T$. asperellum SKT-1 and Phoma sp. GS8-1.

PGPF isolates $P$. simplicissmum GP17-2 and T. asperellum SKT-1 were potentially employed against several plant pathogens (Hyakumachi 1994; Elsharkawy et al. 2012, 2014). Additionally, F. equiseti proved to be effective bioagents in suppressing the infection of soil-borne fungi (Saldajeno and Hyakumachi 2011).

\section{Microscopic examination by scanning electron microscopy}

SEM examination showed typical morphological characteristics and complete fungal growth of S. cepivorum of the control (Fig. 2a). The pathogen developed sclerotia in their right form. However, P. simplicissmum GP17-2 (Fig. 2b) and T. asperellum SKT-1 (Fig. 2c) inhibited the growth of $S$. cepivorum causing morphological anomaly such as coiling, atrophy and lysis of the fungal mycelia. Secretion of antifungal compounds was found to prevent the development of different plant pathogens (Hassan et al. 2014; Elsharkawy et al. 2014). Antifungal substances produced by Trichoderma sp. were considered the key players in controlling the infection with Podosphaera xanthii (El-Kot and Derbalah 2011).

\section{Effect of cultural filtrates of PGPF on germination of sclerotia}

Data in Table 3 showed that all the culture filtrate (CF) treatments of PGPF isolates significantly decreased the germination of sclerotia. Filtrate of $P$. simplicissmum GP17-2 exhibited the best results in this respect, followed by $T$. asperellum SKT-1, Phoma sp. GS8-1, Phoma sp. GS8-3 and F. equiseti GF18-3. The reduction in the germination of sclerotia was $70.85 \%$ due to the CF

Table 4 Effect of plant growth-promoting fungi (PGPF) colonization on the growth of onion plants with or without the infection of Sclerotium cepivorum under greenhouse conditions

\begin{tabular}{|c|c|c|c|c|c|c|c|c|}
\hline \multirow[t]{2}{*}{ Treatments } & \multicolumn{2}{|c|}{ Plant height $(\mathrm{cm})$} & \multicolumn{2}{|c|}{ Root length $(\mathrm{cm})$} & \multicolumn{2}{|c|}{ Bulb perimeter $(\mathrm{cm})$} & \multicolumn{2}{|l|}{ Dry weight (g) } \\
\hline & No pathogen & $\overline{\text { Pathogen }}$ & No pathogen & $\overline{\text { Pathogen }}$ & No pathogen & $\overline{\text { Pathogen }}$ & No pathogen & Pathoger \\
\hline Control & $46.81 \mathrm{e}$ & $5.27 d$ & $11.69 \mathrm{e}$ & $4.76 f$ & $8.52 \mathrm{e}$ & $5.00 f$ & $14.50 \mathrm{~d}$ & $5.08 f$ \\
\hline Folicur & $48.54 d$ & $10.36 b$ & $12.61 d$ & $7.29 c$ & $8.60 \mathrm{e}$ & $12.03 c$ & $14.56 \mathrm{~d}$ & $12.03 \mathrm{C}$ \\
\hline GS8-1 & $54.64 b$ & $12.12 \mathrm{a}$ & $15.17 \mathrm{~b}$ & $8.17 \mathrm{a}$ & $9.75 c$ & $14.36 a$ & $17.59 b$ & $14.36 a$ \\
\hline GS8-3 & $50.48 c$ & $8.43 c$ & $13.92 \mathrm{C}$ & $6.01 d$ & $9.45 \mathrm{~cd}$ & $10.23 d$ & $16.19 c$ & $10.13 d$ \\
\hline SKT-1 & $57.29 a$ & $11.76 a$ & $16.35 a$ & $7.85 b$ & $10.65 a$ & $13.09 b$ & $18.76 a$ & $13.09 \mathrm{~b}$ \\
\hline GF18-3 & $48.81 d$ & $7.95 c$ & $13.01 d$ & $5.64 \mathrm{e}$ & $9.04 d$ & $9.13 e$ & $15.75 c$ & $9.23 \mathrm{e}$ \\
\hline GP17-2 & $56.15 \mathrm{ab}$ & $10.86 b$ & $15.14 b$ & $7.35 c$ & $10.13 b$ & $12.57 \mathrm{bc}$ & $17.92 b$ & $12.57 \mathrm{bc}$ \\
\hline
\end{tabular}

Different letters indicate statistically significant differences between treatments by Fisher's LSD test 
Table 5 Effect of plant growth-promoting fungi (PGPF) colonization on the growth of onion plants infected with Sclerotium cepivorum under field conditions

\begin{tabular}{|c|c|c|c|c|c|c|c|c|c|c|}
\hline \multirow[t]{2}{*}{ Treatments } & \multicolumn{2}{|c|}{ Plant height $(\mathrm{cm})$} & \multicolumn{2}{|c|}{ Root length $(\mathrm{cm})$} & \multicolumn{2}{|c|}{ Bulb perimeter $(\mathrm{cm})$} & \multirow{2}{*}{$\begin{array}{l}\text { Dry weight (g) } \\
\text { 2017-2018 }\end{array}$} & \multicolumn{3}{|c|}{ Yield of bulb $\left(\mathrm{kg} / \mathrm{m}^{2}\right)$} \\
\hline & 2017-2018 & 2018-2019 & 2017-2018 & 2018-2019 & $2017-2018$ & $2018-2019$ & & 2018-2019 & 2017-2018 & 2018-2019 \\
\hline Control & $21.00 f$ & $21.84 \mathrm{e}$ & $6.27 d$ & $8.44 f$ & $5.38 d$ & $6.08 \mathrm{e}$ & $9.24 f$ & $10.45 e$ & $0.81 \mathrm{~g}$ & $0.92 f$ \\
\hline Folicur & $54.75 a$ & $58.92 \mathrm{a}$ & $13.64 a$ & $14.54 a$ & $13.57 a$ & $14.91 \mathrm{a}$ & $22.37 a$ & $23.66 a$ & $2.77 a$ & $3.05 a$ \\
\hline GS8-1 & $43.72 d$ & $49.87 c$ & $10.87 \mathrm{c}$ & $12.59 \mathrm{~cd}$ & $10.84 b$ & $12.58 \mathrm{c}$ & $18.28 \mathrm{~cd}$ & $19.96 \mathrm{c}$ & $2.17 d$ & $2.38 d$ \\
\hline GS8-3 & 42.94de & $45.96 d$ & $10.54 c$ & 12.02de & $10.39 b c$ & $11.29 d$ & 17.15de & $19.13 \mathrm{~cd}$ & $2.06 \mathrm{e}$ & $2.19 \mathrm{e}$ \\
\hline SKT-1 & $48.42 \mathrm{C}$ & $51.69 c$ & $12.58 \mathrm{~b}$ & $13.32 \mathrm{bc}$ & $12.90 \mathrm{a}$ & $13.56 \mathrm{~b}$ & $19.43 b c$ & $21.97 b$ & $2.38 \mathrm{c}$ & $2.57 c$ \\
\hline GF18-3 & $41.23 \mathrm{e}$ & $43.97 d$ & $10.15 c$ & $11.31 \mathrm{e}$ & $9.89 c$ & $11.51 d$ & $16.24 \mathrm{e}$ & $18.63 d$ & $1.88 f$ & $2.11 \mathrm{e}$ \\
\hline GP17-2 & $52.34 b$ & $55.30 \mathrm{~b}$ & $12.97 a b$ & 13.98ab & $13.41 a$ & $14.41 a$ & $20.69 b$ & $22.89 a b$ & $2.50 \mathrm{~b}$ & $2.76 b$ \\
\hline
\end{tabular}

Different letters indicate statistically significant differences between treatments by Fisher's LSD test

of P. simplicissmum GP17-2, while it was $44.01 \%$ in the CF treatment of $F$. equiseti GF18-3.

Excretion of chitinase, cutinase and other cell walldegrading enzymes by bioagents was advocated to perform an important function against fungal pathogens (Tweddell et al. 1994). CFs of PGPF triggered the expression of genes related to defence enzymes such as $\beta-1,3$ glucanases and acidic and basic chitinase (Elsharkawy et al. 2012).

\section{Impact of PGPF on some crop parameters}

Four crop parameters, i.e. plant height, root length, bulb perimeter and plant dry weight, were evaluated at the end of the experiment (100 days post-infection) to determine the effect of PGPF isolates on onion growth. Data presented in Table 4 revealed that crop parameters of plants treated with PGPF isolates were significantly increased than the control plants. Similarly, the PGPFtreated onion plants under the infection of S. cepivorum exhibited significantly increased crop parameters in comparison with the infected control under greenhouse and field conditions (Tables 4 and 5). Additionally, the fungicide Folicur significantly increased the crop parameters than at the control treatment. Several studies have reported the utility of PGPF isolates for promoting plant growth (Saldajeno and Hyakumachi 2011).

\section{Impact of PGPF on disease severity}

Onion seedlings pre-treated with PGPF isolates prior to pathogen inoculation could significantly suppress the white rot symptom improvement than in the control (Fig. 3). Both disease severity and incidence were decreased in response to PGPF treatments in greenhouse and field trials (Tables 6 and 7 , respectively). This result indicated that PGPF protected onion plants against S. cepivorum and reconfirmed previous studies which have shown that PGPF could efficiently reduce the incidence of root diseases (Elsharkawy et al. 2014). P. simplicissmum GP17-2 showed the best results in this respect, while F. equiseti GF18-3 showed the lowest activity against S. cepivorum. Successful biological control of the onion white rot has been reported by a number of

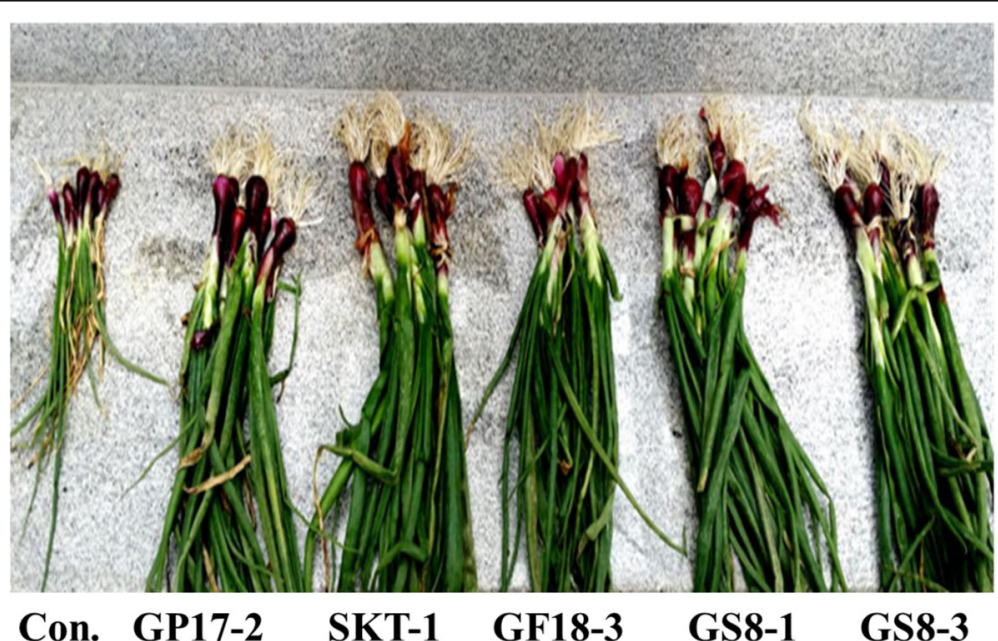

Fig. 3 Effect of PGPF isolates compared with the control treatment on the disease symptoms of onion seedlings infected with white rot (Sclerotium cepivorum) under field conditions 
Table 6 Disease incidence and severity of white rot-infected onion plants treated with barley grain inoculum of plant growth-promoting fungi or with the fungicide (Folicur) relative to non-treated control plants under greenhouse conditions

\begin{tabular}{lll}
\hline Treatments & Disease incidence (\%) & Disease severity (\%) \\
\hline Control & $95.83 \mathrm{a}$ & $92.71 \mathrm{a}$ \\
Folicur & $12.50 \mathrm{~g}$ & $8.37 \mathrm{e}$ \\
GS8-1 & $29.83 \mathrm{~d}$ & $27.78 \mathrm{~b}$ \\
GS8-3 & $33.33 \mathrm{C}$ & $29.17 \mathrm{~b}$ \\
SKT-1 & $20.83 \mathrm{e}$ & $18.75 \mathrm{c}$ \\
GF18-3 & $37.50 \mathrm{~b}$ & $30.21 \mathrm{~b}$ \\
GP17-2 & $16.67 \mathrm{f}$ & $13.55 \mathrm{~d}$ \\
\hline
\end{tabular}

Different letters indicate significant differences by Fisher's LSD test $(P \leq 0.05)$

researchers in glasshouse and field trials, using fungal and bacterial isolates (Abd El-Moity 1976; Clarkson et al. 2002).

\section{Effect of the PGPF on stimulation of peroxidase and polyphenol oxidase}

The readings of peroxidase and polyphenol oxidase were increased in PGPF-treated plants than in the control (Fig. 4). The behaviour of the assessed enzyme was changed based on the inducer PGPF isolate. The P. simplicissmum GP17-2 treatment showed the highest level of defence-related enzyme activities followed by $T$. asperellum SKT-1, Phoma sp. GS8-1, Phoma sp. GS 8-3 and F. equiseti GF18-3. The results of disease severity were highly correlated with the results of enzyme activities. For example, GP17-2 was superior to all PGPF isolates in reducing the disease severity as well as in increasing the activities of peroxidase and polyphenol oxidase enzymes. Maurhofer et al. (1994) also reported varying levels of glucanase and chitinase in tobacco cultivars treated with different isolates of PGPR. Similarly, biochemical analysis of cucumber plants showed increased accumulations of POX and PPO in PGPF-treated plants
Table 7 Disease incidence and severity of white rot-infected onion plants treated with barley grain inoculum of plant growth promoting fungi or with the fungicide (Folicur) relative to nontreated control plants under field conditions

\begin{tabular}{|c|c|c|c|c|}
\hline \multirow[t]{2}{*}{ Treatments } & \multicolumn{2}{|c|}{ Disease incidence (\%) } & \multicolumn{2}{|c|}{ Disease severity (\%) } \\
\hline & 2017-2018 & 2018-2019 & 2017-2018 & 2018-2019 \\
\hline Control & $75.55 a$ & $72.22 \mathrm{a}$ & $80.55 a$ & $77.77 a$ \\
\hline Folicur & $11.11 \mathrm{f}$ & $7.78 f$ & $13.89 f$ & $11.13 e$ \\
\hline GS8-1 & $21.01 \mathrm{~cd}$ & $17.78 \mathrm{c}$ & $30.55 c$ & $22.02 \mathrm{C}$ \\
\hline GS8-3 & $22.22 \mathrm{bc}$ & $20.00 \mathrm{bc}$ & $36.11 b$ & $27.78 b$ \\
\hline SKT-1 & 17.78de & $14.43 d$ & $25.00 d$ & $19.84 c$ \\
\hline GF18-3 & $25.56 b$ & $22.22 b$ & $38.89 b$ & $30.15 b$ \\
\hline GP17-2 & $15.56 \mathrm{e}$ & $11.12 \mathrm{e}$ & $19.45 e$ & $13.89 d$ \\
\hline
\end{tabular}

in comparison with the control (Hassan et al. 2014). The exact role of defence-related enzymes in disease resistance was demonstrated previously (Hassan et al. 2014).

\section{Expression levels of $P R 1$ and $P R 2$ genes}

$C_{\mathrm{T}}$ values were evaluated for $P R 1$ and $P R 2$ genes in PGPF treatments under $S$. cepivorum infection to offer an outline of the relative abundance of PR genes (Fig. 5). The expression of $P R 1$ was significantly high in $P$. simplicissmum GP17-2 treatment with 6.9-folds of the control. PR1 gene was upregulated with the expression levels 5.9, 5.7, 4.8 and 4.7-folds in treatments with $F$. equiseti GF18-3, $T$. asperellum SKT-1, Phoma sp. GS8-1 and Phoma sp. GS $8-3$, respectively. Rapid induction of PR2 gene $(\beta-1,3-$ glucanases) was noticed in PGPF treatments. Expression of $P R 2$ gene exhibited the highest values in P. simplicissmum GP17-2 treatment. In contrast, $P R 2$ gene was slightly induced in Phoma sp. GS 8-3 and the fungicide Folicur recording 3.4 and 2.4-folds, respectively.

The obtained results agree with that of Elsharkawy et al. (2012) who showed that the expression of the defence genes
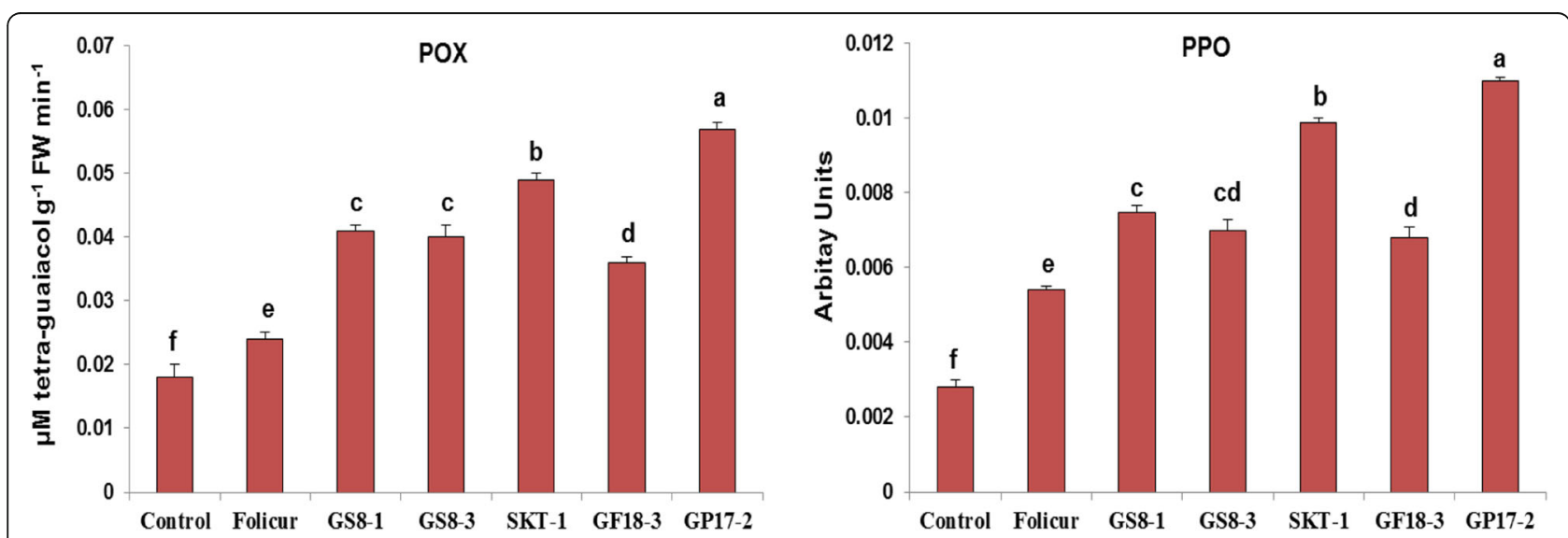

Fig. 4 Activities of peroxidase (POX) and polyphenol oxidase (PPO) enzymes in onion plants treated with PGPF isolates or the fungicide Folicur and infected with Sclerotium cepivorum 


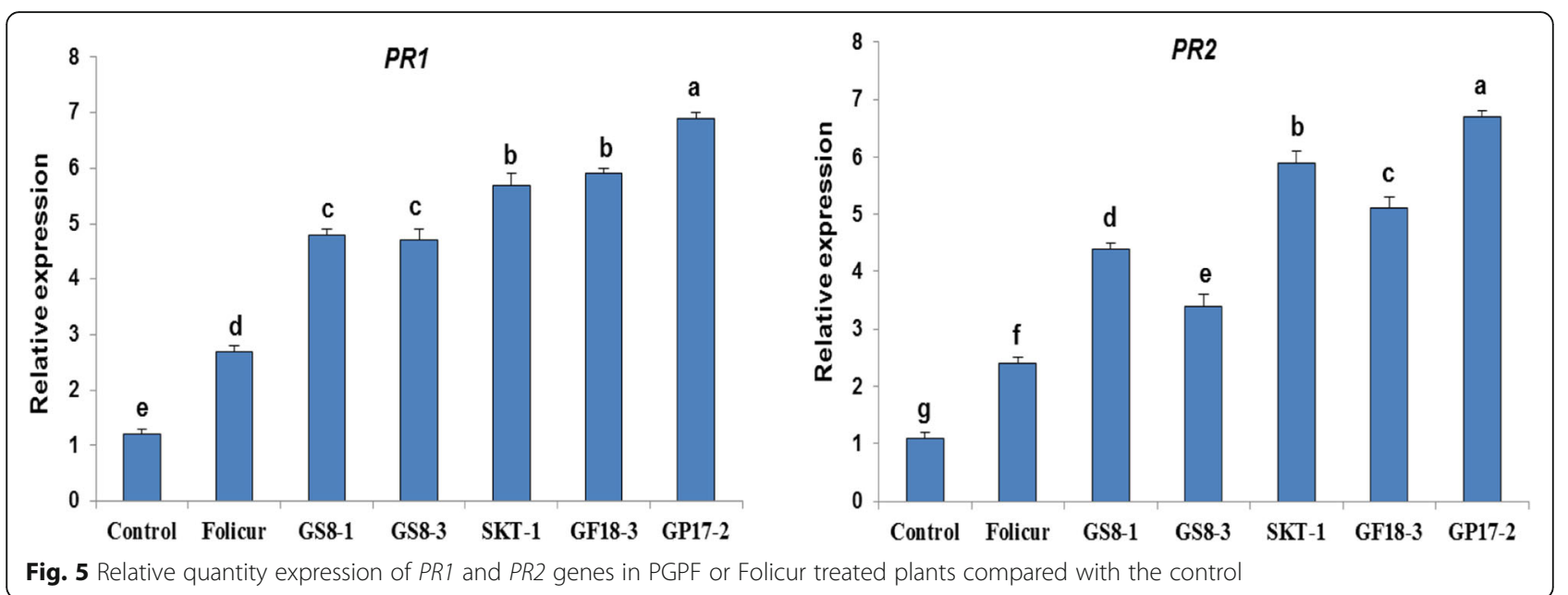

were upregulated in P. simplicissmum GP17-2-treated plants. The main roles of PR1 proteins are still obscure (Urano et al. 2013), although Niderman et al. (1995) explained the antifungal behaviour of PR1 protein in tomato plants. Additionally, stimulation of PR1 gene led to activated resistance of Arabidopsis plants against different viral and fungal pathogens (Hong and Hwang 2005; Elsharkawy et al. 2012).

\section{Conclusion}

The continuing quest for safe and potential biological control agents has directed the efforts toward the exploration of new biocontrol agents that can effectively substitute traditional and harmful pesticides. The obtained results indicated that the tested PGPF isolates can effectively control the white rot disease in onions. Moreover, these isolates significantly increased crop growth parameters. The assayed materials can represent new and potential biocontrol methods for the white rot disease in onions and maybe other pathogens.

\section{Acknowledgements}

The authors greatly acknowledge the staff of the Department of Agricultural Botany, Faculty of Agriculture, Kafr-Elsheikh University, Kafr-Elsheikh, Egypt.

\section{Authors' contributions}

All authors carried out the experiments and wrote the manuscript. All authors read and approved the final version of the manuscript.

\section{Funding}

Funding is by the authors.

Availability of data and materials

All data and materials are available.

\section{Ethics approval and consent to participate}

The ethics committee approved the research article, and all authors agree (consent) to participate in this research article.

\section{Consent for publication}

All authors participated in the work and consent for publication.

\section{Competing interests}

The authors declare that they have no competing interests.

\section{Author details}

'Department of Agricultural Botany (Plant Pathology), Faculty of Agriculture, Kafrelsheikh University, Kafr Elsheikh 33516, Egypt. ${ }^{2}$ Department of Agricultural Botany (Agricultural Microbiology), Faculty of Agriculture, Kafrelsheikh University, Kafr Elsheikh 33516, Egypt.

Received: 11 July 2019 Accepted: 9 October 2019

Published online: 11 November 2019

\section{References}

Abd El-Moity TH (1976) Studies on the biological control of white rot disease of onion. M.Sc. Thesis, Faculty of Agric., Menoufia University, Egypt, p 121

Anand T, Chandrasekaran A, Kuttalam S, Raguchander T, Prakasam V, Samiyappan R (2007) Association of some plant defence enzyme activities with systemic resistance to early leaf blight and leaf spot induced in tomato plants by azoxystrobin and Pseudomonasfluorescens. J Plant Interact 2:233-244

Bell DK, Wells HD, Markham CR (1982) In vitro antagonism of Trichoderma species against six fungal plant pathogens. Phytopathology 72:382-379

Brix HD, Zinkernagel V (1992) Effects of cultivation, conditioning and isolate onsclerotium germination in Sclerotium cepivorum. Plant Pathol 41:13-19

Clarkson J, Payne T, Mead A, Whipps JM (2002) Selection of fungal biological control agents of Sclerotium cepivorum for control of white rot by sclerotial degradation in a UK soil. Plant Pathol 51:735-745

El-Kot G, Derbalah A (2011) Use of cultural filtrates of certain microbial isolates for powdery mildew control in squash. J Plant Prot Res 51(3):252-260

El-Morsi AA, Abdelkhalek AA, El-Shahaby OA, Hafez EE (2015) Pathogenesisrelated genes as tools for discovering the response of onion defense system against Iris yellow spot virus infection. Botany 93(11):735-744

Elsharkawy MM, Hassan N, Villajuan-Abgona R, Hyakumachi M (2014) Mechanism of biological control of Rhizoctonia damping-off of cucumber by a nonpathogenic isolate of binucleate Rhizoctonia. Afr J Biotechnol 13(5):640-650

Elsharkawy MM, Shimizu M, Takahashi H, Hyakumachi M (2012) Induction of systemic resistance against Cucumber mosaic virus by Penicillium simplicissimum GP17-2 in Arabidopsis and tobacco. Plant Pathol 61:964-976

El-Sheshtawi M, El-Gazzar T, Saad AS (2009) Comparative study between chemical and non-chemical control against Sclerotium cepivorum, the causal white rot of onion under Egyptian condition. J Agric Sci Mansoura Univ 34:2169-2182

Gilman JC (1957) A manual of soil Fungi Revised 2nd edn. The lowa State Univ. Press, Ames, p 220

Hassan N, Elsharkawy MM, Shivanna MB, Meera MS, Hyakumachi M (2014) Elevated expression of hydrolases, oxidase, and lyase in susceptible and resistant cucumber cultivars systemically induced with plant growth-promoting fungi against anthracnose. Acta Agric Scand B Soil Plant Sci 64:155-164

Hong JK, Hwang BK (2005) Induction of enhanced disease resistance and oxidative stress tolerance by over expression of pepper basic PR-1 gene in Arabidopsis. Physiol Plant 124:267-277 
Hyakumachi M (1994) Plant growth promoting fungi from turfgrass rhizosphere with potential for disease suppression. Soil Microorg 44:53-58

Hyakumachi M, Mondal SN, Elsharkawy MM, Hassan N (2014) Carbon loss by sclerotia of Sclerotium rolfsii under the influence of soil $\mathrm{pH}$, temperature and matric potential and its effect on sclerotial germination and virulence. Appl Soil Ecol 77:34-41

Livak KJ, Schmittgen TD (2001) Analysis of relative gene expression data using real-time quantitative PCR and the 2(-Delta Delta C(T)) method. Methods 25: 402-408

Maurhofer M, Hase C, Meuwly P, Metraux JP, Defago G (1994) Induction of systemic resistance of Tobacco necrosis virus by the root-colonizing Pseudomonas fluorescens strain CHA0: influence of the gac A gene and of pyoverdine production. Phytopathology 84:139-146

Metcalf DA, Dennis JJC, Wilson CR (2004) Effect of inoculum density of Sclerotium cepivorum on the ability of Trichoderma koningii to suppress white rot of onion. Plant Dis 88:287-291

Niderman T, Genetet I, Bruyère T, Gees R, Stinzi A, Legrand M, Fritig B, Mösinger E (1995) Pathogenesis-related PR1-proteins are antifungal. Isolation and characterization of three 14 kilo Dalton proteins of tomato and of a basic PR1 of tobacco with inhibitory activity against Phytophthora infestans. Plant Physiol 108:17-27

Payghami E (2001) Antagonistic effects of several isolates of Trichoderma on fungi causing onion root rot, East Azarbaidjan Province. Iran J Agric Sci 32: $747-755$

Rasmussen JB, Smith JA, Williams S, Burkhardt W, Ward E, Somerville S, Ryals J Hammerschmidt R (1995) cDNA cloning and systemic expression of a peroxidase associated with systemic acquired resistance in cucumber. Physiol Mol Plant Pathol 46:389-400

Reddy MS (1992) Influence of onion seed bacterization on germination and mycosphere microflora of Sclerotium cepivorum sclerotia. Can J Microbiol 38(11):1135-1143

Ryan EW, Kavanagh T (1976) White rot of onion (Sclerotium cepivorum). 1. Control by fungicidal pelleting of onion seed. Ir J Agric Res 15:317-323

Sadasivam S, Manickam A (1991) Biochemical methods. New Age International Publishers, Chennai, p 256

Saldajeno MGB, Hyakumachi M (2011) The plant growth promoting fungus Fusarium equiseti and the arbuscular mycorrhizal fungus Glomus mosseae stimulate plant growth and reduce severity of anthracnose and damping off diseases in cucumber (Cucumis sativus) seedlings. Ann Appl Biol 159:28-40

Thimmaiah SK (1999) Standard methods of biochemical analysis. Kalyani Publishers, New Delhi, p 545

Tweddell JR, Jabaji-Hare SH, Charest PM (1994) Production of chitinase and $\beta-1$, 3-glucanases by Stachybotrys elegans, a mycoparasite of Rhizoctonia solani. Appl Environ Microbiol 60:489-495

Urano D, Chen JG, Botella JR, Jones AM (2013) Heterotrimeric G protein signalling in the plant kingdom. Open Biol 3:120186

Utkhede RS, Rahe JE (1979) Wet sieving floatation technique for isolation of sclerotia of Sclerotium cepivorum from muck soil. Phytopathology 69:295-297

\section{Publisher's Note}

Springer Nature remains neutral with regard to jurisdictional claims in published maps and institutional affiliations.

\section{Submit your manuscript to a SpringerOpen ${ }^{\circ}$ journal and benefit from:}

- Convenient online submission

- Rigorous peer review

- Open access: articles freely available online

- High visibility within the field

- Retaining the copyright to your article

Submit your next manuscript at $\boldsymbol{\nabla}$ springeropen.com 